(PhD), Institute for Social and Behavioral Research, Iowa State University, USA, 2001.

21 Berking $\mathrm{M}$, Orth $\mathrm{U}$, Lutz $\mathrm{W}$. Effects of systematic feedback to the therapist on patient progress. An empirical study in a cognitive-behavioral inpatient setting (in German). Z KI Psych Psychot 2006; 35: 21-9.

22 Schmidt U, Landau S, Pombo-Carril MG, Bara-Carril N, Reid Y, Murray K, et al. Does personalized feedback improve the outcome of cognitive-behavioura guided self-care in bulimia nervosa? A preliminary randomized controlled trial. Brit J Clin Psychol 2006; 45: 111-21.

23 Brodey BB, Cuffel B, McCulloch J, Tani S, Maruish M, Brodey I, et al. The acceptability and effectiveness of patient-reported assessments and feedback in a managed behavioral healthcare setting. Am J Manag Care 2005; 11: 774-80.

24 Slade $M$, Mccrone $\mathrm{P}$, Kuipers $\mathrm{E}$, Leese $\mathrm{M}$, Cahill S, Parabiaghi $\mathrm{A}$, et al. Use of standardised outcome measures in adult mental health services. Randomised controlled trial. Br J Psychiatry 2006; 189: 330-6.

25 Whipple JL, Lambert MJ, Vermeersch DA, Smart DW, Nielsen SL, Hawkins EJ. Improving the effects of psychotherapy: the use of early identification of treatment and problem-solving strategies in routine practice. $J$ Couns Psychol 2003; 50: 59-68.

26 Ashaye OA, Livingston G, Orrell MW. Does standardized needs assessment improve the outcome of psychiatric day hospital care for older people? A randomized controlled trial. Aging Ment Health 2003; 7: 195-9.
27 Marshall M, Lockwood A, Green G, Zajac-Roles G, Roberts C, Harrison G. Systematic assessments of need and care planning in severe mental illness: cluster randomised controlled trial. Br J Psychiatry 2004; 185: 163-8.

28 Lambert MJ, Burlingame GM, Umphress V J, Hansen N B, Vermeersch D A Clouse G, et al. The reliability and validity of the Outcome Questionnaire. Clin Psychol Psychoth 1996; 3: 106-16.

29 Becker T, Vazquez-Barquero JL. The European perspective of psychiatric reform. Acta Psych Scand 2001; 104: 8-14.

30 Lambert MJ, Hansen NB, Finch AE. Patient-focused research: using patient outcome data to enhance treatment effects. J Consult Clin Psych 2001; 69 159-72.

31 Lueger RJ, Howard Kl, Martinovich Z, Lutz W, Anderson EE, Grissom G. Assesssing treatment progress of individual patients using expected treatment response models. J Consult Clin Psych 2001; 69: 150-8.

32 Kordy H, Hannöver W, Richard M. Computer-assisted feedback-driven quality management for psychotherapy: the Stuttgart-Heidelberg model. J Consult Clin Psych 2001; 69: 173-83.

33 Hatfield DR, Ogles BM. The use of outcome measures by psychologists in clinical practice. Prof Psychol Res Pr 2004; 35: 485-91.

34 Gilbody SM, House AO, Sheldon TA. Psychiatrists in the UK do not use outcome measures. National survey. Br J Psychiatry 2002; 180: 101-3.

35 Jacobson NS, Truax P. Clinical significance: a statistical approach to defining meaningful change in psychotherapy research. J Consult Clin Psych 1991; 59: $12-9$

\section{Psychiatrists in 19th-century fiction}

\section{The Yellow Wallpaper (1892), Charlotte Perkins Gilman}

\author{
Fiona Subotsky
}

The narrator of The Yellow Wallpaper has been taken by her medical husband to 'a colonial mansion, a hereditary estate', perhaps 'a haunted house', to recover from 'a temporary nervous depression - a slight hysterical tendency'. She has been forbidden to write, though she does so secretly, and is increasingly confined to her bedroom at the top of the house, an old nursery with barred windows, a heavy bed fastened to the floor and badly damaged yellow wallpaper with a strange pattern and smell which becomes increasingly hideous yet fascinating to her. Weeks go by. She seems to see behind the pattern a woman, or many women, creeping, as if behind bars, and tries to release her or them by creeping round the walls herself and stripping off the paper. The ending is both shocking and uncertain, in itself deranged.

Where is the psychiatrist in this? The narrator's husband says that if she does not improve, he will send her 'to Weir Mitchell in the fall'. Silas Weir Mitchell was in fact an eminent contemporary physician in the United States, author both of scientific books and papers and also of a considerable amount of fiction. He had treated Charlotte Perkins Gilman for depression, in her view disastrously. He was especially famous for his 'rest cure', which required his patients, usually women considered to be suffering from hysterical nervous complaints, to be confined to bed and do nothing exciting at all but passively undergo electrical and massage treatments and consume a large quantity of food. He described his method in Fat and Blood, and How to Make Them (1877). While highly fashionable for a while, by 1896 our own Journal concluded that this treatment 'has frequently proved a most conspicuous failure'.

Charlotte Gilman, however, did escape her confines and became an active feminist lecturer and writer; her novel has become a feminist classic. 